\title{
Islam Moderat antara Konsep dan Praksis di Indonesia
}

\author{
Dani Sartika
}

\begin{abstract}
The Islamic moderation is the efforts to tend the tradition and making the equalled idea of gracious Islam. The purpose of this research is to delve the moderate Islam which becomes the deals between the right extreme group and the left extreme group. This is the solution from many horizontal conflicts which is caused by the different perception of religion nowadays. The method that used by the researcher in this study is the scientific method analysis. This analysis is the way which is using many procedures to analysing and making the valid conclusion from the document. In this implementation, the writer researches many literatures, manuscript, particularly the education journals to study which is related to this research. The result from the research finds that popularizing Islam moderate in Indonesia is the obligation. The concern Islam is not only about worship, but also caring to all Muslims, moreover for all the human being with the different background own. Regarding and caring the natural sustainability is the Islamic teaching of hablum minal alam obligaton. Created as rahmatan lil 'alamanin thought, that is one of the Islam moderate reference, returning the real of Islam which is known as the religion of full of grace and affection. The Islam moderate or also called wasatiyyah al-islam is Islam which always indicated by harmony, impartiality, wisdom, tolerance, acceptance, respect, inclusive, non-violence, non-extremism, non-radicalism and non-terrorism. The existence of living safe, peacefulness, and welfare in this world is according to Islam. That is one of the biggest religion in the world. With the thought which is prioritizing social approach, nationality, culture and humanity.
\end{abstract}

Keywords: Moderate Islam, harmony, inclusive, peaceful

\section{Pendahuluan}

Indonesia oleh Tuhan penguasa alam raya diberi anugerah luar biasa berupa kekayaan alam dan keragaman entitas. Tak perlu ditanya lagi soal kekayaan alam yang di bumi Indonesia, mulai dari melimpahnya barang tambang, keanekaragaman hayati, tanah yang subur, serta hasil laut yang melimpah. Sedangkan keragaman yang ada di Indonesia meliputi keragaman dalam aspek keagamaan, suku bangsa, bahasa, dan juga budaya. Pada titik ini saya hendak menyitir salah satu ayat al-Qur'an, "Nikmat Tuhan mana lagi yang hendak kau dustakan?" (Q.S. Ar-Rohman: 13). 
Baik kekayaan alam maupun keragaman entitas tersebut tentu saja tak ubahnya pisau bermata dua, yang bisa berpotensi bagi kemajuan bangsa dan bisa pula berpotensi menimbulkan berbagai macam permasalahan. Perbedaan tersebut terletak dari bagaimana cara kita memanfaatkan kekayaan alam dan menyikapi keragaman tersebut.

Terkait dengan keragaman budaya yang dimiliki Indonesia, sikap pluralisme dan multikulturalisme merupakan sebuah keharusan yang tak bisa lagi ditawar. Pasalnya, sikap tersebut memberikan pengakuan kepada mereka yang meski secara jumlah tidak banyak, tetapi ada di sekitar kita. Mereka berhak memeroleh pengakuan yang sama untuk status kepemilikan etnis, agama atau lainnya. Multikultaralisme juga akan menghindarkan terjadinya dikotomi antara "kita" (kelompok dominan) dan "mereka"(kelompok minoritas) (Musa Asy'ari, Kompas, 2004).

Akan lebih mengerikan lagi apabila dikotomi antara kelompok mayoritas dan minoritas sebagaimana disebutkan di atas, dilembagakan dalam rangka menjauhkan kelompok minoritas dari akses kekuasaan. Para founding father negeri ini tahu benar, bahwa tanpa kesadaran akan keragaman dan beragama tak mungkin kesejahteraan dan kemakmuran bangsa Indonesia bisa terwujud. kiranya menjadi relevan apabila didiskusikan konsep Islam Moderat dan Praksisnya di Indonesia.

\section{METODE}

Penulisan artikel ini menggunakan metode studi perbandingan literatur dan analisis konten. Kegiatan membandingkan literatur satu dengan literatur lain dilakukan untuk mengungkap berbagai teori dan informasi yang relevan dengan topik yang dikaji. Studi dengan membandingkan literatur satu dengan literatur lain dilakukan dengan menelusuri literatur primer secara daring, yaitu jurnal, laporan penelitian, laporan kegiatan, buku, majalah, media berita, dan sumber literatur lainnya, yang memiliki kriteria valid dan bereputasi baik. Jurnal, prosiding, dan buku yang digunakan diprioritaskan berasal dari database Scopus (https://www.scopus.com/home.uri), dan ERIC Institute of Education (https://eric.ed.gov/). Literatur juga diperoleh dari Google Cendekia (https://scholar.google.co.id/), khusus literatur berbahasa Indonesia, literatur yang diterbitkan di Indonesia, dan literatur yang ditulis oleh author dari Indonesia. Literatur lainnya ditelusur menggunakan mesin pencari Google. Kata kunci yang digunakan untuk menelusur literatur menggunakan bahasa Indonesia, yaitu Islam Moderat, Keseimbangan, Inklusif, Damai.

Tahapan dalam kegiatan membandingkan literatur satu dengan literatur lain yang digunakan dalam menyusun artikel ini mengacu pada Zed (2008) dan Khatibah (2011). Ada empat langkah yang harus dilakukan, yaitu (1) mempersiapkan peralatan: dalam bentuk pensil/ballpoint, buku catatan, dan komputer/laptop yang terhubung dengan jaringan internal; (2) menyusun 
bibliografi; (3) mengatur waktu dan fokus pada kegiatan; dan (4) membaca secara cermat, mencatat, dan menulis hasil.

Analisis data menggunakan paradigma analisis konten. Penyajian data menggunakan metode presentasi informal. Dalam penyajian data, penulis mengikutsertakan kutipan dari berbagai referensi yang digunakan, dalam bentuk hasil analisis, menyebutkan sumber dan diilustrasikan berdasarkan ringkasan atau esensi informasi (yang bisa saja akan berbentuk parafrase berbeda namun tetap sama makna) untuk setiap topik yang dianalisis. Hal tersebut dilakukan dengan konteks pemikiran kritis dan analisis informasi secara mendalam.

\section{HASIL DAN PEMBAHASAN}

\section{Konsep Islam populer}

Secara umum, banyak kalangan berpandangan bahwa term Islam popular adalah perwujudan metamorfosis Islam yang telah mengalami akulturasi dengan kebudayaan kekinian (baca: modernisme). Akulturasi tersebut secara signifikan mengubah wajah Islam masa kini, yang sebelumnya tampil dalam wajah dan suasana konservatif dan tradisional, kini tampil berubah lebih universal, sehingga mampu menyentuh segala elemen, dan hinggap dalam tatanan kehidupan masyarakat Muslim secara umum. Dalam pengertian ini, Islam popular direpresentasikan oleh hadirnya beragam fenomena kontemporer yang sebelumnya telah mengalami Islamisasi. Baik itu dalam masalah yang diangkat dalam penulisan hal penampilan, musik, bahasa, fashion, seni, maupun menyangkut perilaku (Raharjo, 2015 : 12). Jika mengacu pada penjelasan ini, maka Islam popular sesungguhnya lebih pada representasi adaptasi Islam terhadap perkembangan zaman. Dalam bahasa George lucas, Islam pada era mengalami proses komodifikasi diri agar dapat menemukan tempatnya di tengah perubahan sosial.

Secara definitif, Islam popular memiliki pengertian yang cukup beragam, karena keberadaannya dapat ditinjau dari banyak perspektif. Sekurangkurangnya Weintraub (2011) mendefinisikan Islam popular dalam empat pengertian. Pertama, adanya akulturasi kebudayaan dan tradisi lokal yang berbaur dengan ajaran sufisme Islam. perbauran tersebut menyebabkan adanya lahirnya satu ritual atau adat Islam lokal. Dalam kaitan ini, Islam menjalin kontak atau hubungan dengan tradisi lokal tertentu. ajaran Islam tidak memaksakan dirinya menampilkan wujud asli secara tekstual, namun berbaur dalam wujud ritual yang saling mengisi.

Di Indonesia, perbauran antara Islam dan tradisi lokal ada dalam wajah Islam sikretisme. Kedua, Islam populer adalah wujud kebudayaan postmodernime. Bahwa Islam popular bukan semata wujud kebudayaan modernism Islam, namun di atas dari itu. Postmodernisme mempunyai satu diri khas kebudayaan yang terletak pada seni dan tampilan. Islam Populer dalam perspektif ini cenderung menitikbretakan pada universalitas dalam memaknai 
Islam dan mengimplementasikannya berdasarkan subtansi. Ketiga, pemahaman Islam popular merujuk pada pola keIslaman yang inklusif. Yakni satu karakter keberagaman yang senantiasa abersikap terbuka terhadap kelompok atau paham keagamaan dari luar.

Beradaptasi dengan dinamika masyarakat sehingga ajaran Islam dapat dilaksanakan secara praktis dalam masyarakat. Keempat, Islam popular merupakan satu paham gerakan Islam kontemporer yang bertujuan untuk mengembangkan dan memajukan pembangunan masyarakat Islam (Weintraub, 2011).

Pada kesempatan yang lain, Haryanto dalam Wasito Raharjo Jati (2015) menjelaskan, bahwa fenomena Islam popular dalam dinamikan keIslaman berakar dari dua peristiwa atau sejarah besar. Pertama, kemunculan Islam popular adalah wujud dari formalisasi agama atas marjinalisasi kelas selama rezim otoritarian. Persitiwa ini sesungguhnya merupakan potret ketidakberdayaan kelas Muslim dalam sektor politik akibat tekanan kekuasaan. Marjinalisasi kelas membuat kedudukan sosial Muslim mengalami keterasingan. Terutama dari lingkungan mereka selaku kelompok mayoritas.

Dengan demikian, Islam popular adalah satu wujud upaya perlawanan kelas sosial Muslim atas hegemoni kelompok otoritarian. Ketidakmampuan rezim menjawab sekian persoalan sosial yang menghimpit kehidupan masyarakat di banyak sektor, terutama yang bersentuhan dengan kesejahteraan, menjadi momentum besar bagi mereka untuk menampakkan diri di tengah masyarakat. Kedua, kemunculan Islam Populer dihubungkan dengan maraknya praktik kapitalisasi agama. Dalam kaitan ini, Islam populer dipandang sebagai upaya komodifikasi agama untuk memenuhi kepentingan kepentingan ekonomis (Raharjo, $2015: 14$ ).

Berdasarkan kemunculannya, perilaku dan ritual Islam popular di Indonesia dapat dikelompokkan menjadi tiga arus besar, yakni arus Arab Saudi, Iran, dan Mesir-Turki. Islam popular yang berkiblat pada Arab Saudi merujuk pada sikap, pemikiran, dan perilaku keagamaan yang diadopsi dari tradisi keagamaan Arab Saudi. Cara keagamaan seperti pemeliharaan jenggot panjang, pemakaian celana cingkrang, cadar dan lain sebagainya, kesemuanya adalah simbol keagamaan popular yang tergolong dalam kelompok ini. Di Indonesia, kelompok keIslaman ini dapat di identifikasi pada keberadaan kelompok kelas menengah, seperti Hizbut Tahrir Indonesia (HTI), Majelis Mujahidin Indonesia (MMI). Sedangkan Islam popular yang bersumber dari Iran, pada umumnya merupakan pola, sikap, perilaku, dan pemikiran keagamaan yang sifatnya tradisionalis. Beberapa ritual Islam seperti barzanji, shalawat, kenduri, permadani, dan intelektualisme Qom, kesemuanya tergolong dalam kelompok ini.

Dalam realitas keIslaman Indonesia, berbagai praktik keagaman Islam popular Iran, mayoritas Ada dan dipraktikkan di lingkungan pesantren dan pedesaan. Selain dari Iran dan Arab Saudi, Islam popular Indonesia juga 
diproduksi dari Mesir-Turki. Beberapa aktivitas keagaman seperti kelompok intelektual kampus, kelompok kelas menengah urban, dan majelis ta'lim, kesemuanya merupakan wujud keagaman Islam popular yang sangat dekat tradisi dan kebudayan Islam Turki-Mesir (Raharjo, 2015 : 24).

\section{Konsep tentang Islam moderat}

Dalam banyak kajian, term moderat di satu sisi senantiasa disandingkan dengan Islam yang ramah pada alam sosial, dan di sisi lain merupakan anti tesis terhadap term Islam puritan. Dalam kacamata umum, Islam moderat seringkali diidentifikasi karakteristik keIslaman universal. Menitikberatkan pada keseimbangan antara Islam kiri yang dikenal puritan dan Islam kanan yang identik dengan pandangan normatif. Islam moderat mengambil tempat di tengah, tidak condong ke kanan dan tidak pula condong ke kiri. Ibaratkan pemikiran trialektika Hegelian, jika Islam kanan adalah tesis, dan antitesisnya adalah Islam kiri, maka isma moderat adalah sebuah gerakan Islamisme yang mendudukkan dirinya sebagai sebuah sintesa.

Dengan demikian, bisa dikata bahwa Islam moderat adalah wujud mediasi antar dua tarikan Islam ekstrim, yakni Islam kanan dan Islam kiri. Tidak saling menyalahkan, tidak menyatakan paling benar sendiri, dan bersedia berdialog, sehingga tercermin bahwa perbedaan itu benar-benar rahmat. Jika ini yang dijadikan pijakan dalam beramal dan beragama, maka inilah sebenarnya makna konsep slam moderat (Abdurrohman, 2018: 1). Sedangkan dalam pengertian lainnya Islam moderat adalah Islam yang selalu ditandai oleh keseimbangan, keadilan, kebajikan, toleransi, tenggang rasa, respek, inklusif, anti kekerasan, ekstremisme, radikalisme dan terorisme. (Ainusyamsi, 2020 : 20).

Secara etimologi, berdasarkan Kamus Besar Bahasa Indonesia (KBBI), moderat mempunyai arti sebagai sikap yang senantiasa menghindari perilaku atau pengungkapan yang ekstrim. Kata kunci penting di sini adalah menghindari, perilaku/pengungkapan, dan ekstrim. Ekstrem berarti paling ujung, paling sangat, paling keras, fanatik, hal yang keterlaluan. Jika merujuk pada definisi ini, maka Islam moderat mengisyaratkan atas usaha sadar menjauhkan cara keberagaman (Islam) yang jauh dari berbuat kasar, keras, dan keterlaluan. Baik itu dalam bersikap, berpikir, berucap, ataupun bertindak.

Sederhananya, moderat dalam pengertian etimologi menitikberatkan pada penghiasan sikap dan perilaku diri yang halus. Karenanya, sosiolog Muslim kontemporer, Khaled Abu Fadl dalam Rusdi (2009) menggolongkan kata moderat sebagai lawan kata dari puritan. Puritan sendiri menurut Khaled Abu Fadl dalam Rusdi (2009) adalah satu ciri gerakan Islamisme yang berorientasi-kekuasaan yang menyerukan kembali kepada identitas Islam otentik melalui penerapan syariat Islam (Rusli, 2009: 1 ).

Dalam kesempatan yang lain, term moderat jika ditinjau dari Oxford Advanced Learner's Dictionary dalam bahasa Inggris memiliki kepadanan dengan kata moderate, yang artinya; average in amount, intensity, quality, etc; 
not extreme (ratarata dalam jumlah, intensitas, kualitas, dan lain-lain; tidak ekstrem); of or having (su political) opinions that are not extreme (pandangan politik yang tidak ekstrem); keeping or kept within limits that are not excessive (menjaga dalam batas- batas yang tidak berlebihan).

Jika merujuk pada sekian pengertian tersebut, term moderat dalam bahasa Inggris lebih cenderung dekat pada ihwal politik. Namun demikian, secara subtansial, baik moderat dalam versi bahasa Inggris maupun alam arti KBBI, keduanya sama-sama menekankan pada perwujudan sikap atau perilaku nir kekerasan dan ekstrimesme secara umum.

Adapun dalam bahasa Arab, moderat senantiasa diselaraskan dengan kata al-tawassut (tengah), al- i,tidal (adil), dan semacamnya. Dalam banyak kesempatan, sejumlah kalangan pemikir Islam, istilah di atas seringkali diidentifikasi untuk menggolongkan satu sikap atau perilaku keagamaan yang tidak mengedepankan pendekatan kekerasan dan kekasaran. Terutama menyangkut ihwal permasalahan, perdebatan, dan perbincangan diskursus keagamaan yang bersentuhan dengan wilayah teologis (Hilmy, 2012:2 ).

Sikap tawassuth representasi pola keberagaman yang di satu sisi tidak memiliki keberpihakan pada kelompok Islam kanan, dan di sisi lain juga tidak condong pada kelompok kiri. Karena sikapnya inilah kebanyakan penganut Islam normatif, kelompok moderat dianggap tidak ggambarkan semangat keberagamaan (girah diniyah) yang kuat (Khan, 2005 : 5 ). Di banyak negara, term tawassuth adalah satu karakteristik keIslaman yang mempunyai kedekatan dan keintiman begitu kuat dengan nilai- nilai lokalitas. Baik itu dalam hal kebudayaan, tradisi, maupun adat istiadat.

Adapun dalam pengertian terminologinya, Hilmy (2012) menggarisbawahi term Islam moderat sebagai istilah yang merujuk pada mereka yang menolak pemberlakuan kekerasan sebagai garis ideologi dan perjuangannya. Penolakan kekerasan dalam aspek ideologi sama artinya dengan menjauhkan cara berpikir dan cara pandang diri dari setiap pola berpikir yang beroientasi pada kekerasan. Moderatisme dalam berideologi artinya menjunjung tinggi keluasan, kedalaman, dan keseimbangan dalam berpikir dan menalar. Menghindari pola pikir yang kaku, jumud, pembacaan dan penafsiran aspek-aspek teologis yang tekstual.

Berideologi secara moderat adalah perwujudan pandangan sosial keagamaan kritis, sehingga pada gilirannya dapat menghindarkan individu dari pemikiran dan perilaku keagaman yang sempit. Perjuangan diri, baik dalam hal agama mupun politik, terletak pada kuatnya akar toleransi dan pluralitas sistem keyakinan dan kepercayaan mereka.

Ciri khas paling mendasar dari kesemuanya adalah kesediaan diri untuk menerima dan hidup berdampingan dengan golongan atau kelompok keagaman di luar mereka. Pada batasan-batasan tertentu, pun juga mereka sikap dan pandangan keagamaan yang mengakui atas kebenaran ajaran-ajaran keagamaan di luar dirinya (baca: inklusif). Karena kriterianya yang demikian, 
sejumlah kalangan menilai bahwa Muslim moderat seringkali diindikasikan sebagai kelompok yang pro-Barat dalam visi politiknya ataupun yang kritis dalam pemikiran keagamaannya (Khan, 2005 : 5).

Terlepas dari pembacaan etimologi maupun terminologi di atas, secara umum term moderatisme memuat makna jalan tengah (middleway). Jika Antony Giddens mendudukkan istilah jalan tengah sebagai solusi atas tarikan dua binner madzhab politik global, antara sosialisme dan kapitalisme, maka Islam moderat adalah perwujudan jalang tengah di antara dua kutub ekstremes gerakan Islamisme kontemporer, yakni radikal dan liberal.

Kelompok Islam radikal adalah satu wujud pemikiran dan gerakan Islam yang memuat pandangan fudamentalisme sekterian. Sedangkan Islam liberal adalah wajah kelompok keIslaman yang mendasarkan dirinya pada teologi kapitalistik yang mereduksi pemikiran mereka pada semangat etika protestan seperti yang diperkenalkan oleh Max Weber. Dalam tradisi pemikiran keagamaan, kutub ekstremitas seringkali didefinisikan sebagai al-guluw-Yusuf al- Qardhawi sering menyebutnya sebagai al- mutatarrif dan moderatisme sering disebut sebagai al-wasth yang berarti jalan tengah (middle-path atau middle- way) (Hans, 1979).

\section{Karakteristik Islam moderat}

Menurut Erich Kolig dan Greg Fealy dalam Hilmy (2012), berdasarkan hasil penelitian kedunya didapati sebuah fakta, bahwa konsep term moderatisme dalam Islam, menemukan rujukan dan batasan yang jelas rinci dan jelas (Abdurrohman, 2018 : 5). Secara tekstual, pendefinisian dan pencirian term moderat dalam diskursus keIslaman, hingga detik ini masih menjadi satu diskursus keagamaan yang abu-abu. Ketidakjelasan sekat perihal konsep moderat dalam tubuh Islam di sini tenggarai oleh minimnya sumber teologis yang membicarakan kedudukan atau hubungan antara moderat dan Islam. Paling dominan, wacana perihal moderatisme sejauh muncul sebagai respon pemikir atau cendekiawan Muslim atas adanya perilaku atau pemikiran yang berbau ekstremisme.

Dalam beberapa kesempatan, kata Moderat diidentikkan banyak kalangan dengan kata modernis (Rusli, 2009 : 1). Hal ini mungkin berlandaskan pada tipologi keduanya yang sama-sama menekankan pada kedalaman perpikir dan bertindak. Moderat, sebagaiman telah disinggung sebelumnya, memiliki ciri khas pola pikir yang dinamis dan luas. Dalam batasan-batasan tertentu, sistem berpikir demikian mempunyai keselarasan dengan kelompok Muslim modernis. Sebuah gerakan keislaman yang mulai intensif penggunaannya ketika memasuki awal abad $20 \mathrm{M}$. Tepatnya setelah ada usaha dan gerakan pembaharuan pemikiran di beberapa negara mayoritas berpenduduk Islam. Termasuk di dalamnya Indonesia (Nata, 2001: 23).

Jika Islam moderat diterima sebagai jelmaan lain dari Islam modernis, maka Islam moderat sebagaimana ciri khas Islam modernis dapat diidentifikasi 
sebagai gerakan atau pemikiran keIslaman yang mengedepankan semangat berpikir ilmiah menurut fitrah dan hukum sunnatullah. Dinamis, luwes, dan progressif sesuai dengan perkembangan ilmu pengetahuan. Sekurangkurangnya terdapat dua ciri mendasar. Pertama, rasional. Rasoinal artinya sebuah paradigma keagaman yang menempatkan teks-teks keagamaan berdasarkan nalar dan daya pikir yang dialektik. Dengan hubungan yang dialektik itulah agama dan akal dapat menjalin sinergitas, sehingga teks-teks keagamaan menyangkut kehidupan manusia dapat ditafsirkan dan dimaknai secara komprehensif, kontekstual, dan menyeluruh. Kedua, ilmiah. Sikap ilmiah di sini mengandaikan pada kesediaan, kesanggupan, dan penerimaan diri terhadap produk- produk ilmu pengetahuan (Nata, 2001 : 34).

Kaum Islam moderat mempunyai semangat berpikir ilmiah, mereka menerima dan mendudukan ilmu pengetahuan sebagai instrument mengarungi kehidupan. Dalam kaitan ini aspek pengetahuan dan religiusitas keagamaan menjalin kebersamaan dan berdampingan. Sehingga satu sama lain tidak saling menafikan, atau bahkan dibenturkan. Pada kesempatan yang lain, Din Syamsudin, cendikiawan Muslim kontemporer Indonesia, pada acara Konferensi Tingkat Tinggi Muslim Dunia (2018) merumuskan bahwa Islam moderat adalah pandangan keIslaman yang memuat empat aspek penting, yakni rasional, toleran, bertenggang rasa, dan tepa selera (Kompas, 2018).

Rasional, seperti yang telah dijelaskan di atas, adalah cara keberIslaman yang menempatkan akal sebagai patner agama. Akal melalui kemampuan dan kecanggihan bernalarnya berkedudukan sebagai instrumen di mana bahasabahasa mistik agama diterjemahkan, ditafsirkan, dan dimaknai. Dengan peran akal, maka pesan agama yang sebelumnya berada dalam alam abstrak dapat dibumikan secara nyata ke dalam kehidupan masyarakat.

Adapun toleran dalam Kamus Besar Bahasa Indonesia (KBBI) diartikan sebagai suatu sikap atau sifat yang (menghargai, membiarkan, membolehkan) pendirian (pendapat, pandangan, kepercayaan, kebiasaan, kelakuan, dan sebagainya) yang berbeda atau bertentangan dengan pendirian sendiri. Berlandaskan pengertian ini, toleran dalam berIslam yang moderat mengandaikan pada perwujukan sikap keberagaman yang senantiasa terbuka dan membuka diri pada setiap bentuk keagamaan yang di luarnya. Baik itu menyangkut pemikiran, ritual, ajaran, dan sebagainya.

Dalam diskursus keagamaan global, perilaku keberagaman yang toleran juga dibahasakan sebagai cara keagamaan yang inklusif. Yaitu satu perilaku keagamaan yang memiliki kecenderungan untuk melebur dengan agamaagama lain di luar keyakinan. Perlawanan dari inklusif adalah eksklusif. Kebalikannya, pola keberagaman eksklusif memiliki kecenderungan menutup diri. Mempunyai kesadaran yang rendah melakukan kerjasama dengan golonga lain yang tidak sejalan dengan paham dan agama mereka.

Ciri ketiga Islam moderat dalam rumusan Din Syamsudin adalah tenggang rasa. Secara etimologi, dalam Wiktionary tenggang rasa memiliki arti dapat 
(ikut) menghargai (menghormati) perasaan orang lain. Pengertian ini memiliki kesaaam dengan Kamus Besar Bahasa Indonesia (KBBI). Adapun secara terminologi tenggang rasa dipahami sebagai suatu sikap hidup dalam ucapan, perbuatan, dan tingkah laku yang mencerminkan sikap menghargai dan menghormati orang lain (Wikipedia, 2018). Jika merujuk pada pengertian ini, maka berIslam moderat mensyaratkan atas perwujudan diri yang senantiasa menjunjung tinggi rasa kasih sayang, penghormatan, dan penghargaan kepada setiap orang yang memiliki latar (paham) keagamaan berlainan dengan kepercayaan kita. Sederhananya, moderat artinya bertenggang rasa yang pada puncaknya ada kesadaran, kesediaan, dan kesanggupan diri merangkul orang lain.

Secara definitif, tenggang rasa terlihat mempunyai kesamaan dengan toleransi. Kedua term ini sama- sama mempunyai makna peghormatan antara satu kelompok terhadap kelompok lainnya. Sepintas memang sama, namun dalam penerapannya sesungguhnya ada perbedaan cukup mendasar. Toleransi pada hakikatnya merupakan kesediaan diri menjaga perasaan kita terhadap perbuatan, perilaku, dan sikap orang lain.

Dalam hal ini, orang yang memiliki sikap toleransi tinggi umumnya akan mudah memafkan oran lain. Adapun tenggang rasa kesanggupan diri menjaga perasaan orang lain terhadap perbuatan, sikap, dan tindakan kita. Sehingga dapat dikatakan setiap orang yang memiliki sifat tenggang rasa, maka dirinya akan selalu berhati-hati dalam setiap perilaku, sikap, dan tindakannya. Mereka yang memiliki sikap toleran yang berlebihan disebut permisif, sebaliknya jika tidak memiliki toleransi sama sekali disebut fanatik. Sedangkan terlalu mempunyai sikap tenggang rasa disebut paranoid, adapun sebutan cuek atau ignorance merupakan istilah bagi mereka yang tidak mempunyai sikang tenggang rasa sama sekali.

Ciri terakhir Islam moderat menurut Din Syamsudin adalah tepa selera. Dalam Kamus Besar Bahasa Indonesia (KBBI) tepa selera merujuk pada pengertian; dapat merasakan (menjaga) perasaan (beban pikiran) orang lain sehingga tidak menyinggung perasaan atau meringankan beban orang lain; tenggang rasa dan toleransi. Jika mengacu pada pembacaan ini, maka dapat diklaim bahwa tepa selira sesungguhnya merupakan penggabungan dua sikap, yakni toleransi dan tenggang rasa. Di satu sisi mempunyai kesadaran untuk bersikap toleran, dan pada sisi yang bersamaan juga mempunyai kesadaran bersikap tenggang rasa. Sederhananya, tepa selerasa adalah memiliki perhatian ganda, perhatian terhadap perasaan orang lain, dan perhatian terhadap perilaku diri.

Jika mengacu pada keseluruhan kriteria dan karakteristik di atas, apa yang disebut dengan Islam moderat sejatinya telah lama ada dalam realitas kehidupan Indonesia. Baik dalam wujud kultural maupun struktural, Bahkan keseluruhan nilai moderat tersebut sudah menjadi satu cerminan hidup yang diajarkan dalam berbangsa dan bergenara. Secara kultural, nilai-nilai moderat 
tercermin jelas dalam dimensi sosio kultur masyarakat Indonesia. Kenyataan ini tergambar jelas dalam pola kehidupan mereka, di mana ada hubungan begitu kuat antara perilaku dengan nilai kebudayaan yang berlaku di kehidupan mereka. dalam kaitan ini, dapat disimpulkan bahwa wujud perilaku masyarakat Indonesia adalah representasi kehadiran budaya dan tradisi lokal yang khas berdasarkan tipografi Indonesia yang majemuk, plural, dan beraneka ragam.

Adapun secara struktural, nilai kemoderatan Indonesia tergambar jelas dalam bangunan struktur kebangsaan dan kenegaraan. Bangunan dasar tersebut merujuk pada keberadaan dua filosfis negara yang hari ini dikenal dengan Pancasila dan Bhinneka Tunggal Ika. Pancasila sebagai dasar filosofis negara adalah wujud konstitusional yang dapat ditafsiri sebagai pengakuan sekaligus penegasan negara atas kewajiban berlaku moderat. Menjunjung tinggi keadilan, dan bersikap bijak dalam merspons sekian perbedaan. Baik perbedaan tersebut berbentuk kebudayaan, tradisi, suku, bahkan dalam wilayah (paham) keagamaan sekalipun.

Selain pancasila, kita juga mengenal Bhinneka Tunggal Ika. Satu semboyan bangsa-negara yang di dalamnya mengandung pesan bahwa, di tengah kemajemukan dan keanekaragaman bangsa Indonesia perlu adanya sikap moderat. Yakni sikap yang berisikan kesediaan dan kesanggupan diri untuk mengakui dan merangkul semua elemen perbedaan yang ada di sekitar. Baik itu dalam dimensi budaya, tradisi, bahkan dalam wilayah yang sensitif sekalipun, Agama misalnya.

\section{Potret Islam moderat di Indonesia: Dari NU hingga Muhammadiyah}

Disadari atau tidak, perbincangan Islam modera di Indonesia merupakan satu tema keagamaan yang tidak saja penting namun juga menarik. Dikatakan menarik karena sebagaimana kita ketahui bersama, bahwa Indonesia adalah satu wujud negara yang memiliki ciri geografis yang majemuk. Terdiri dari ratusan, bahkan ribuan pulau. Masing-masing pulau dipenuhi oleh suku dan etnis berbeda. Setiap dari mereka mempunyai latar kebudayaan, adat, tradisi, bahkan sistem dan wujud kepercayaan (baca: agama) berbeda antara satu dengan lainnya. Fakta atas segala perbedaan ini adalah bukti nyata betapa Indonesia merupakan negera plural yang keberadaannya harus dijaga, dirawat, dikelola, bahkan harus diimbangi oleh satu bangunan sistem peraturan yang dapat merangkul semuanya. Dalam kaitan ini, membincang Islam moderat sama kedudukannya membicarakan realitas Indonesia yang majemuk dan bhinneka. Kemajemukan dan kebhinnekaan Indonesia ada satu kelebihan dan kekayaan Indonesia yang tidak saja khas, unik, namun juga suatu yang menarik di mata Negara lainnya.

Pada saat bersamaan, diskursus Islam moderat di Indonesia dianggap penting karena dalam kenyataannya, saat ini ada banyak sikap, perilaku, dan tindakan sentimen keagamaan yang cenderung anarkis, kasar, dan memuat kekerasan. Gejala ke arah tersebut nampak jelas dalam realitas 
(paham/kelompok) keagamaan Indonesia saat ini. Ada banyak pristiwa pergesekan, perselisihan, bahkan hingga aksi persekusi antara satu sama lain. Puncak dari semuanya adalah menggeliatnya benturan dan konflik antara (paham) keagamaan yang secara nyata menjadi ancaman besar. Bukan saja bagi stabilitas bangsa negara, namun juga bagi keutuhan Negara Kesatuan Republik Indonesia (NKRI), sebagaimana dipertontonkan oleh kelompok atau paham keagamaan beralirkan fundamentalisme dan ekstrimesme.

Di Indonesia, term Islam moderat sejatinya sudah bergulir sejak lama, perbincangan tentangnya telah diangkat dalam banyak kesempatan. Di sektor politik, terutama pada awal masa transisi demokrasi Indonesia pasca bergulirnya reformasi tahun 1998, term Islam moderat digaungkan secara besar- besaran. Tujuannya tidak lain adalah untuk menyelaraskan hubungan demokrasi dan Islam, yang saat itu memantik perdebatan banyak kalangan. Sejumlah kelompok menganggap demokrasi dapat didudukkan bersama, karena keduanya adalah satu pandangan hidup universal yang menawarkan satu bangunan visi-misi sama.

Dalam sejarah keagamaan (Islam) di Indonesia, keberIslaman moderat sesungguhnya secara praktik sudah telah diperkenalkan. Terutama melalui nilai ajaran keIslaman yang dibawa oleh Walisongo (Abdurrohman, 2018 : 16). Berdasarkan penelusuran Mas'ud (2006) Walisongo merupakan sosok pelaku dakwah abad XV-XVI yang dikenal berhasil mengintegrasikan aspek keagamaan dengan produk kebudayaan atau tradisi di luarnya. Memadukan kebiasaan masyarakat yang bersifat transinden dengan suatu yang profan. Melalui model dakwah mereka yang mengusung prinsip kultural, walisongo berhasil memperkenalkan wajah kerahmatan Islam dengan cara elegan. Cara tersebut secara signifikan berhasil mempengaruhi banyak masyarakat. Berdasarkan fakta sejarah, bahwa dengan cara menoleransi tradisi lokal serta memodifikasinya ke dalam ajaran Islam dan tetap bersandar pada prinsipprinsip Islam. Dalam kenyataannya, agama baru ini dipeluk oleh bangsawanbangsawan serta mayoritas masyarakat Jawa di pesisir utara (Abdurrohman, $2018: 45)$.

Kehadiran wajah Islam Indonesia yang mengusung semanagat kearifan lokal, meminjam bahasa Azyumardi Azra, merupakan karakter asli dari wujud keberilsman Nusantara (Indonesia) yang moderat (Basya, 2018 : 9), bahwa Islam dan demokrasi tidak dapat bersandingan. Demokrasi adalah sistem tata kelola pemerintahan yang lahir dari rahim kebudayaan barat. Sebaliknya, Islam memiliki sudut pandang sendiri perihal bagaimana mengelola dan membentuk sistem pemerintahan.

Pada saat bersamaan, sejumlah kalangan (Muslim) menegaskan bahwa Islam dan berkenaan dengan keberIslaman nusantara ini, Mark Woodward dalam studinya mebemukan fakta, bahwa jika ditelaah secara mendalam dan ditinjau dari segi perspektif Islam secara luas, didapati bahwa hampir seluruh ajaran, tradisi, dan penekanan yang bersifat spiritual yang selama ini 
berkembang dalam masyarakat Jawa, pada dasarnya bersumber dari ajaran Islam di Timur Tengah. Apa yang dikenal dalam upacara keagamaan Jawa, seperti grebeg, selametan, kalimasodo, adalah bagian dari ajaran Islam. Selain itu, doktrin Kawula Gusti Martabat Tujuh dan tradisi wayang yang dikenal dan dilestarikan dalam masyarakat Jawa, dapat ditelusuri asal usulnya dari tradisi tasawuf Islam (Shihab, 1997 : 70).

Dalam konteks dinamika keIslaman Indonesia kontemporer, term Islam moderat selama ini disandarkan pada dua organisasi keIslaman besar, yakni Nahdhatul Ulama' (NU) dan Muhammadiyah. Meski ada dalam kutub berlainan, namun keduanya diikat oleh kesamaan pandangan untuk menjalankan fungsi kerahmatan Islam, yakni menghadirkan satu rupa keagamaan yang berkesesuaian dengan realitas kebangsaan Indonesia. Bangsa yang terbentuk di atas tipologi masyarakat yang majemuk, bhinneka, plural, dan beraneka ragam. Dalam NU, sikap keberIslaman moderat tercermin nyata dari komitmen mereka untuk menghadirkan satu karakteristik keIslaman yang dapat bersanding mesra dengan nilai-nilai lokalitas. Meminjam konsepnya Syafi'i Ma'arif (2009), menumbuhkan cara berislam dalam Bingkai Keindonesiaan, Sedangkan daalam Muhammadiyah, keberIslaman moderat terletak dalam semangat mereka dalam upaya melakukan proyek pembaruan. Senantiasa melanjalankan agenda revitalisasi studi keIslaman.

Menumbuhkan semangat tajdid dalam upaya menselaraskan teks-teks keagamaan dengan semangat pembangunan kekinian. Agenda rethinking keIslaman yang dilakukan Muhammadiyah, pada batasan-batasan tertentu, berhasil melahirkan paradigma keberIslaman modern. Di satu sisi terbuka terhadap perkembangan zaman, namun di sisi lain tetap berakar kuat pada subtansi keagamaan Islam.

Bagi NU sendiri, menyebut mereka sebagai kelompok Islam moderat merupakan satu kewajaran. Jika ditelusuri lebih jauh, klaim moderat terhadap keberadaan NU bukan semata terletak pada semangat keIslaman mereka yang bias kultural. Lebih dari itu, ada pada semangat ajaran mereka yang termuat dalam tiga prinsip, yakni al-tawâssuth (berada di tengah), i'tidâl (tegak lurus, tidak condong ke kanan atau ke kiri), dan al-tawâzun (keseimbangan, tidak berat sebelah antara dimensi duniawi dan ukhrawi) (Muzadi, 2007 : 54). Demikian tercantum jelas dalam Muqaddimah Anggaran Dasar Nahdlatul Ulama 2010.

"Untuk mewujudkan hubungan antar-bangsa yang adil, damai dan manusiawi menuntut saling pengertian dan saling memerlukan, maka Nahdlatul Ulama bertekad untuk mengembangkan ukhuwwah Islamiyah, ukhuwwah Wathaniyah, dan ukhuwwah Insaniyah yang mengemban kepentingan nasional dan internasional dengan berpegang teguh pada prinsip-prinsip al-ikhlas (ketulusan), al-adalah (keadilan), al-tawassut (moderasi), altawazun (keseimbangan), dan al- tasamuh (toleransi)"

Jika ditelusuri lebih mendalam, trilogi ajaran NU sebagaimana tercantum jelas dalam anggaran dasar di atas, kesemuanya merupakan hasil perasan dari 
sumber tertinggi Islam, yakni Al-Qur'an. Ajaran tentang al- tawâssuth adalah turunan dari Surat al- Baqarah ayat 143. Sedangkan konsep al-i'tidal diproduksi dari Surat al- Ma'idah, ayat 8. Adapun ajaran al- tawâzun merupakan turunan dari Surat al- Hadîd ayat 25. Dalam tradisi NU, ketiga ajaran tersebut adalah kesatuan nilai dalam beragama yang harus ditransformasikan sedalam mungkin ke semua aktivitas kehidupan sehari-hari. Baik itu menyangkut aktivitas yang murni berkaitan dengan keagamaan seperti ritual dan keilmuan, maupun ke dalam sektor sosial seperti dalam bergaul, berkomunikasi, atau bahkan dalam berhubungan dengan (paham) keagamaan di luar mereka. Dalam hal akidah, syariah, akhlak, pergaulan antar-golongan, kehidupan bernegara, kebudayaan, dakwah dan bidang-bidang lainnya (Shiddiq, 2006 : 20).

Penjelasan di atas memiliki keselarasan dengan banyak kajian yang telah dilakukan sebelumnya, berkenaan dengan hubungan NU dengan Islam moderat di Indonesia, klaim bahwa NU memiliki karakter dan ciri keagamaan moderat pada dasarnya sudah sudah banyak diungkap. Studi yang dilakukan Muhammad Ali, Masdar Hilmy, dan Ahmad Najib Burhani, dan Toto Suharto, kesemuanya sepakat mengkategorisasikan NU bukan saja sebagai Islam moderat, namun juga memiliki kedudukan sebagai kelompok Islam mainstream di Indonesia, melebih ormas lain, bahkan dengan Muhammadiyah sendiri yang sejauh dianggap mempunyai paradigma lebih modernis.

Adapun Muhammadiyah, sikap mereka terhadap term Islam moderat mempunyai keseragaman dengan NU. Bahwa Muhamadiyah, meski dalam beberapa kajian seringkali dibenturkan dengan ormas NU, pada kenyatannya sama-sama memuat tradisi keberIslaman yang mengusung spirit moderat. Klaim moderatisme Muhammadiyah di sini secara nyata dapat kita temukan dalam banyak kajian. Salah satunya adalah studi yang dilakukan Burhani (2012), di mana dirinya mengkaji perihal sikap religius Muhammadiyah terhadap isu keagamaan kontemporer yang belakangan muncul dalam diskursus keIslaman, seperti pluralisme, liberalisme dan Islamisme (Suharto, $2014: 1$ ).

Secara umum, sikap keberIslaman Moderat Muhammadiyah tercermin jelas berdasarkan hasil Tanwir Muhammadiyah yang berlangsung di Bandung tahun 2012, yang dirumuskan dalam Kristalisasi Ideologi dan Khittah Muhammadiyah. Salah satu keputusannya adalah penajaman ideologi Muhammadiyah, yakni ideologi Islam berkemajuan yang menempatkan Islam sebagai Din al- Hadarah. Rumusan Islam kerkemajuan di sini selanjutnya dikontekstualisasikan melalui beberapa karakter, yakni; pertama, tajdid. Bahwa dalam upaya menjalankan agenda pembaruan, perlu ditumbuhkan semangat ijtihad yang mendasarkan kuat kepada al-Qur'an dan Sunnah. Kedua, menanamkan semangat dan corak reformis-modernis yang bersifatkan wasatîyah (tengah, moderat).

Karakter wasatiyah (tengah/moderat) ciri khas sekaligus pembeda Muhammadiyah dengan ormas lain yang menganut paham dan perilaku 
ekstrim. Ketiga, mengedepankan sikap prokemajuan dan anti- kejumudan, properdamaian dan anti-kekerasan, prokeadilan dan anti- penindasan, prokesamaan dan anti- dikriminasi. Keempat, menjunjung tinggi nilai-nilai utama yang autentik sesuai jiwa ajaran Islam (Nashir, 2015 : 12).

Berdasarkan ideologi, ajaran, dan nilai d moderat ini, jelas menunjukkan bahwa Nahdhatul Ulama' (NU) dan Muhammadiyah merupakan miniatur kemoderatan Indonesia. Baik dalam beragama, berbangsa, bersosial, dan dan bernegara yang mutlak berbeda dengan gerakan Islam radikal-liberal yang memiliki kecenderungan berperilaku berlebihan. Pun juga berbeda dengan gerakam Islamisme radikal-fundamentalis yang senantiasa berorientas pada pemaknaan dan pemahaman Islam secara kaku dan normatif. Seperti halnya kelompok Islam beralirkan Salafi, Wahabi, dan kelompok Islam HTI yang secara nyata memberi ancaman cukup besar bagi Kesatuan Negara Republik Indonesia.

\section{KESIMPULAN}

Secara teologis, gagasan Islam moderat sesungguhnya belum menemukan dasar kuat. Baik dalam lingkup pengertian, karakteristik, maupun dalam praktiknya. Namun berdasarkan banyak kajian dan pemikiran cendekiawan Muslim, mereka sepakat bahwa Islam moderat adalah perilaku keagamana Islam yang memiliki ketegasan untuk bersikap di tengah. Paling penting dari semuanya adalah kesediaan diri untuk menjauhkan sikap kebaragamaan yang memuat tindakan ekstrim. Dalam konteks keindonesiaan, Islam moderat ini direpresentasikan oleh dua ormas Islam besar, yakni Nahdhatul Ulama (NU) dan Muhammadiyah.

Diturunkan sebagai ajaran yang rahmatan lil 'alamin, begitulah salah satu rujukan dari islam moderat, mengembalikan fitrah islam yang dikenal dengan agama yang penuh rahmat dan kasih sayang. Islam moderat atau disebut juga wasatiyyah al-islam adalah islam yang selalu ditandai oleh keseimbangan, keadilan, kebajikan, toleransi, tenggang rasa, respek, inklusif, anti kekerasan, ekstremisme, radikalisme dan terorisme. Terciptanya kehidupan yang aman, damai, dan mensejahterakan di Dunia ini, bergantung pada islam sebagai salah satu agama terbesar di Dunia. Dengan ajaran yang mengedepankan pendekatan sosial, kenegaraan, kebangsaan, kebudayaan dan kemanusiaan.

\section{DAFTAR PUSTAKA}

Abdullah S (2007) Pesantren, Jati Diri dan Pencerahan Masyarakat Cetakan I. Sumenep: Said Abdullah Istitute Publishing.

Abdullah MA (1996) Studi Agama Normativitas atau Historisita? Yogyakarta: Pustaka Pelajar. 
Abdurrohman A (2018) Eksistensi Islam Moderat dalam perspektif Islam. Jurnal Rausyan Fikr.

Amin T (2017) Wawasan keislaman dan Kebangsaan di Era Kontemporer. Yogyakarta : Dialektika.

Ainusyamsi, F.A. (2020). Islam Moderat, Bandung: Madani Institute.

Basya MH (2018) Menelusuri Artikulasi Islam Moderat di Indonesia. http://www.madina, diakses tanggal 27 November 2020.

Burhani AN (2012) Al-Tawassut wa-l'tidal: The NU and moderatism in Indonesian Islam. Asian Journal of Social Science 40.

Hans (1979) Modern Written Arabic. Gçttingen: Otto Harrassowitz Verlag.

Hilmy M (2012) Quo-vadis Islam moderat Indonesia? Menimbang kembali modernisme Nahdlatul Ulama dan Muhammadiyah. Jurnal MIQOT 36.

Idahram S (2011) Sejarah Berdarah Sekte Salafi Wahabi. Yogyakarta: Pustaka Pesantren.

Khan MAM (2005) Islamic democracy and moderate Muslims: The straight path runs through the middle. American Journal of Islamic Social Sciences 22 .

Koentjaraningrat (1987) Kebudayaan Mentalitas dan Pembangunan. Jakarta: PT Gramedia Anggota Ikapi.

Ma'arif AS (2009) Islam dalam Bingkai Keindonesiaan dan Kemanusiaan: Sebuah Refleksi Sejarah. Bandung: Mizan.

Madjid N (1993) Islam kemodernan dan Ke-Islaman. Bandung: Mizan.

Mas'ud A (2006) Dari Haramain ke Nusantara: Jejak Intelektual Arsitek Pesantren. Jakarta : Kencana.

Muzadi AM (2007) NU dalam Perspektif Sejarah \& Ajaran: Refleksi 65 Th Ikut NU. Surabaya : Khalista.

Nashir H (2015) Memahami Ideologi Muhammadiyah. Yogyakarta: Suara Muhammadiyah.

Nata HA (2001) Peta keragaman Pemikiran Islam di Indonesia. Jakarta : Rajawali Press.

Oxford Advanced Learner's Dictionary (1994) Oxford: Oxford University Press 798.

Raharjo WJ (2015) Islam popular sebagai pencarian identitas Muslim kelas menengah Indonesia. Jurnal Teosofi: Jurnal Tasawuf dan Pemikiran Islam

Rusli (2009) Gagasan Khaled Abu Fadl tentang Islam moderat versus Islam puritan: Perspektif Sosiologi pengetahuan. Jurnal Ilmu Ushuluddin. 
Shiddiq A (2006) Khittah Nahdliyyah. Surabaya : Khalista-LTN NU Jawa Timur.

Shihab A (1997) Islam Inklusif: Menuju Sikap Terbuka dalam Beragama. Bandung : Mizan.

Sitompul EM (1989) Nahdlatul Ulama dan Pancasila. Jakarta : Pustaka Sinar Harapan.

Suharto T (2014) Gagasan pendidikan Muhammadiyah dan NU sebagai potret pendidikan Islam moderat di Indonesia. Jurnal ISLAMICA: Jurnal Studi Keislaman.

Taufiqurrahman (2007). Identitas budaya Madura. Jurnal Karsa.

Weintraub AN (2011) The Study of Islam and Popular Culture in Indonesia dan Malaysia, dalam Andrew N. Weintrau dkk, Islam and Popular Culture in Indonesia and Malaysia. New York: Routledge.

Wirartha IM (2006) Metodologi Penelitian Sosial Ekonomi. Yogyakarta: CV. Andi Offset. 